\title{
Mechanical ventilation for acute postoperative respiratory failure after surgery for bronchial carcinoma
}

\author{
CJW HIRSCHLER-SCHULTE, BS HYLKEMA, RW MEYER \\ From the Departments of Pulmonary Diseases, Thoracic Surgery, and Respiratory Intensive Care, the \\ University Hospital Groningen, The Netherlands
}

\begin{abstract}
From 1978 to 1982365 patients were treated surgically for bronchial carcinoma. Lobectomy was performed in 250 and pneumonectomy in 115 . Sixteen $(4.4 \%)$ needed mechanical ventilation for acute respiratory failure. Six out of eight with a lobectomy, but only two out of eight with a pneumonectomy, survived initially. Of these eight survivors, five died from recurrent malignancy within a year but three were alive and well at two years. The complications leading to acute respiratory failure were unpredictable in most patients. Improving techniques of mechanical ventilation and intensive care may lead to better results in the future.
\end{abstract}

Previously published work contains many data on the early and late results of surgery for bronchial carcinoma, but most studies have been concerned with operative morbidity and mortality, subsequent lung function, ${ }^{1-11}$ and long term survival. ${ }^{11-14}$ Data on postoperative acute respiratory failure necessitating mechanical ventilation are scarce and lack detail." We are not aware of any study that describes in detail the causes, course, and outcome of this uncommon but menacing complication. We therefore studied retrospectively, all patients who underwent mechanical ventilation for acute respiratory failure within 30 days after undergoing lobectomy or pneumonectomy for bronchial carcinoma. All other patients undergoing thoracotomy were excluded. In particular, we tried to answer the following questions: (1) which factors caused acute respiratory failure and are these factors predictable and preventable? (2) should patients with acute respiratory failure after lobectomy or pneumonectomy be accepted for mechanical ventilation? (3) is the long term prognosis in survivors determined by respiratory function?

Address for reprint requests: C J W Hirschler-Schulte, Department of Pulmonary Diseases, Clinic of Internal Medicine, University Hospital Groningen, 9713 EZ Groningen, The Netherlands.

Accepted 16 January 1985

\section{Patients and methods}

Of 365 patients who had surgical treatment ( 250 lobectomies, 115 pneumonectomies) for cancer other than small cell carcinoma during the five years $1978-82,16(4 \cdot 4 \%)$ were admitted to the respiratory intensive care unit. All patients needed mechanical ventilation within 30 days after operation. All were men, aged 45-74 (mean 63) years. Retrospectively we studied preoperative state, intraoperative and postoperative course, and, in survivors, follow up for at least two years.

\section{Results}

The table shows the main characteristics, course, and outcome in the 16 patients.

\section{Type of operation}

Eight patients underwent a pneumonectomy (six right, two left) and eight a lobectomy. The operation was considered curative in 11 patients and noncurative in five (according to TNM classification).

\section{Indication for mechanical ventilation}

In two patients (cases 1 and 6) postoperative mechanical ventilation was planned ahead because of expected problems. In the remainder mechanical ventilation was needed for totally or largely unexpected intraoperative or postoperative events: 10 patients needed mechanical ventilation from the day 
Clinical features of patients receiving postoperative mechanical ventilation (MV)

\begin{tabular}{|c|c|c|c|c|c|c|c|c|}
\hline $\begin{array}{l}\text { Case } \\
\text { No }\end{array}$ & $\begin{array}{l}\text { Age } \\
\text { (years) }\end{array}$ & $\begin{array}{l}\text { Preoperative } \\
\text { factors }\end{array}$ & Resection & $\begin{array}{l}\text { Intraoperative } \\
\text { problems }\end{array}$ & $\begin{array}{l}\text { Reason for } M V \\
\text { and timing }\end{array}$ & $\begin{array}{l}\text { Duration of } M V \\
\text { Istay in RICU } \\
\text { (days) }\end{array}$ & Course in RICU & Result \\
\hline 1 & 67 & $\begin{array}{l}\text { COLD with } \\
\text { infections; VC 2 l; } \\
\text { FEV, 52\% }\end{array}$ & LU lobe & & $\begin{array}{l}\text { Prophylaxis } \\
\text { Postoperatively }\end{array}$ & $1 / 7$ & $\begin{array}{l}\text { Bleeding from chest } \\
\text { drain, bronchoconstriction } \\
\text { and atelectasis }\end{array}$ & $\begin{array}{l}\text { Died in hospital } \\
\text { with bronchocon- } \\
\text { striction and } \\
\text { respiratory failur }\end{array}$ \\
\hline 2 & 71 & & RU lobe & & $\begin{array}{l}\text { Fistula on day } 1 ; \\
\text { MV from day } 10\end{array}$ & $43 / 44$ & $\begin{array}{l}\text { Thoracotomy and closure } \\
\text { fistula on MV; gradual } \\
\text { recovery }\end{array}$ & Well at 2 years \\
\hline 3 & 71 & $\begin{array}{l}\text { COLD, steroids; } \\
\text { VC } 4.4 \text { l; FEV } 139 \%\end{array}$ & RL lobe & $\begin{array}{l}\text { Severe broncho- } \\
\text { constriction }\end{array}$ & $\begin{array}{l}\text { Respiratory failure } \\
5 \text { hours } \\
\text { postoperatively }\end{array}$ & $1 / 4$ & Recovery & Well at 2 years \\
\hline 4 & 69 & & LL lobe & & $\begin{array}{l}\text { Hypoventilation } \\
\text { postoperatively }\end{array}$ & $1 / 2$ & Recovery & Well at 2 years \\
\hline 5 & 64 & $\begin{array}{l}\text { COLD, bronchiect- } \\
\text { asis, ECG abnormal; } \\
\text { VC 4.1 l; FEV } 39 \%\end{array}$ & RU lobe & & $\begin{array}{l}\text { Atelectasis of RLL } \\
\text { on day } 2\end{array}$ & $2 / 4$ & Recovery & $\begin{array}{l}\text { Died at } 5 \text { months } \\
\text { with SVC } \\
\text { obstruction }\end{array}$ \\
\hline 6 & 62 & $\begin{array}{l}\text { COLD, previous } \\
\text { cardiac failure; } \\
\text { VC } 4.1 \text { l; FEV, } 49 \%\end{array}$ & LU lobe & & $\begin{array}{l}\text { Prophylaxis } \\
\text { postoperatively }\end{array}$ & $1 / 2$ & Recovery & $\begin{array}{l}\text { Died at } 4 \text { months } \\
\text { with metastases }\end{array}$ \\
\hline 7 & 74 & ECG abnormal & RU lobe & $\begin{array}{l}\text { Bleeding, PA } \\
\text { clamped for } 15 \\
\text { minutes }\end{array}$ & $\begin{array}{l}\text { Elective } \\
\text { postoperatively }\end{array}$ & $1 / 2$ & Recovery & $\begin{array}{l}\text { Died at } 5 \text { months } \\
\text { with metastases }\end{array}$ \\
\hline 8 & 69 & $\begin{array}{l}\text { Previous LU } \\
\text { lobectomy }\end{array}$ & RU lobe* & & Atelectasis on day 5 & $3 / 4$ & $\begin{array}{l}\text { Respiratory and cardiac } \\
\text { failure; died in RICU }\end{array}$ & \\
\hline 9 & 63 & $\begin{array}{l}\text { COLD; VC } 4.7 \text { l; } \\
\text { FEV }, 50 \%^{-50}\end{array}$ & $\mathbf{R}$ lung & & $\begin{array}{l}\text { Thromboembolism } \\
\text { MV from day } 16\end{array}$ & $4 / 4$ & $\begin{array}{l}\text { Pulmonary embolism, } \\
\text { fistula, pneumonia; died } \\
\text { in RICU }\end{array}$ & \\
\hline 10 & 73 & $\begin{array}{l}\text { COLD, ECG } \\
\text { abnormal; VC 4.0 l; } \\
\text { FEV }, 60 \%^{\text {1 }}\end{array}$ & $\mathbf{R}$ lung & & $\begin{array}{l}\text { Bronchoconstriction } \\
6 \text { hours } \\
\text { postoperatively }\end{array}$ & $11 / 11$ & $\begin{array}{l}\text { Bronchoconstriction, } \\
\text { fistula, pneumonia; died } \\
\text { in RICU }\end{array}$ & \\
\hline 11 & 45 & & $\mathbf{R}$ lung* & $\begin{array}{l}\text { Aspiration of } \\
\text { blood L lung }\end{array}$ & $\begin{array}{l}\text { Elective } \\
\text { postoperatively }\end{array}$ & $12 / 14$ & Recovery with difficulties & $\begin{array}{l}\text { Died at } 3 \text { months } \\
\text { with metastases }\end{array}$ \\
\hline 12 & 61 & $\begin{array}{l}\text { COLD, previous } \\
\text { CVA, ECG } \\
\text { abnormal; VC } 2.7 \text { l; } \\
\text { FEV }, 60 \%^{\text {1 } 60 \%}\end{array}$ & L lung* & $\begin{array}{l}\text { Cardiac arrest } \\
\text { pacemaker }\end{array}$ & $\begin{array}{l}\text { Elective } \\
\text { postoperatively }\end{array}$ & $10 / 12$ & Recovery with difficulties & $\begin{array}{l}\text { Died at } 2 \text { months } \\
\text { with metastases }\end{array}$ \\
\hline 13 & 50 & & $\mathbf{R}$ lung* & $\begin{array}{l}\text { Aspiration of } \\
\text { blood L lung; } \\
\text { cardiac arrest }\end{array}$ & $\begin{array}{l}\text { Elective } \\
\text { postoperatively }\end{array}$ & $2 / 8$ & $\begin{array}{l}\text { Brain damage; died } \\
\text { in RICU }\end{array}$ & \\
\hline 14 & 58 & $\begin{array}{l}\text { Diabetes, } \\
\text { schizophrenia }\end{array}$ & $\mathbf{R}$ lung & $\begin{array}{l}\text { Aspiration of } \\
\text { blood L lung }\end{array}$ & $\begin{array}{l}\text { Elective } \\
\text { postoperatively }\end{array}$ & $6 / 6$ & $\begin{array}{l}\text { Pneumonia and circulatory } \\
\text { failure; died in RICU }\end{array}$ & \\
\hline 15 & 60 & $\begin{array}{l}\text { COLD, sarcoid, } \\
\text { steroids; VC 4.0 l; } \\
\text { FEV, 52\% }\end{array}$ & L lung & $\begin{array}{l}\text { Adhesions and } \\
\text { haemorrhage }\end{array}$ & $\begin{array}{l}\text { Elective } \\
\text { postoperatively }\end{array}$ & $7 / 7$ & $\begin{array}{l}\text { Pneumonia and circulatory } \\
\text { failure; died in RICU }\end{array}$ & \\
\hline 16 & 50 & $\begin{array}{l}\text { Poor general } \\
\text { condition }\end{array}$ & $\mathbf{R}$ lung* & Adhesions & $\begin{array}{l}\text { Elective } \\
\text { postoperatively }\end{array}$ & $5 / 5$ & $\begin{array}{l}\text { Multiple organ failure; } \\
\text { died in RICU }\end{array}$ & \\
\hline
\end{tabular}

${ }^{*}$ Resection thought not to be curative. RICU = respiratory intensive care unit; COLD = chronic obstructive lung disease.

of operation, seven of them because of intraoperative difficulties (cases 7, 11-16), and three needed reintubation and mechanical ventilation within a few hours (cases 3,4, and 10). The four others needed to be ventilated between two and 16 days after operation (cases 2, 5, 8, and 9). Duration of mechanical ventilation ranged from six hours to 43 days, and the mean duration of stay in the respiratory intensive care unit was 8.5 days.

\section{Estimated preoperative risk}

Before operation only four patients had no known abnormalities that could be considered to put him or her at high risk. Eight patients had chronic obstruc-

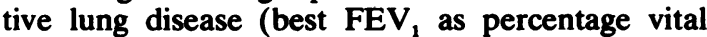
capacity (VC) 39-60\%-all but one with a normal carbon dioxide tension) and four of these also had cardiac abnormalities (three with an abnormal electrocardiogram and one with previous cardiac failure). One other patient had an abnormal electrocardiogram, and three others had different risk factors.

\section{Intraoperative problems}

In eight patients severe unexpected problems developed during operation: six had local problems with massive bleeding or adhesions, or both; one (a patient with atrial fibrillation) had circulatory arrest; and one had severe bronchoconstriction, which was unrelieved by conventional measures before the end of the operation (case 3).

Course in the respiratory intensive care unit Of the four patients not at high risk, one died 
because of massive bleeding, aspiration of blood, and irreversible cerebral damage. Of the eight patients with chronic obstructive lung disease three died in the respiratory intensive care unit because of consolidating pneumonia in combination with other factors (cases 9, 10, and 15). One patient with a previous hypercarbic episode (case 1) died three days after he left the respiratory intensive care unit because of recurrent, irreversible bronchoconstriction. The other patients with chronic obstructive lung disease had only temporary problems, ranging from bronchoconstriction to atelectasis, and survived. The patient with an abnormal ECG as the only risk factor had no circulatory problems and survived (No 7). Six out of eight patients with a pneumonectomy died, but only one out of eight with a lobectomy died. The overall mortality was seven out of $16(44 \%)$.

\section{Fistula formation}

Bronchopleural fistula was seen in three patients; in one patient (case 2) a fistula existed before mechanical ventilation was started and was the main cause of respiratory failure; in the second (case 10) a fistula developed during mechanical ventilation; in the third (case 9) a fistula was a terminal event. In one patient (case 11) a small fistula was suspected but could not be proved. Of these four patients, two died, but in only one (case 10) was the fistula the main cause of death.

\section{Follow up}

Two patients with a pneumonectomy and seven with a lobectomy left the respiratory intensive care unit. After the early death of one (case 1) eight patients remained for follow up. Three of them were alive at two years; the other five died of recurrent local or metastatic malignancy, although three of these were considered to have had a curative resection.

\section{Discussion}

The mortality within 30 days after lung resection for bronchial carcinoma ranges from $4-7 \%$ for lobectomy and from $6-10 \%$ for pneumonectomy 28111214 and is higher after a right sided pneumonectomy than after a left sided one $( \pm 13 v \pm 5 \%) .^{81114}$ Cardiopulmonary complications (pneumonia, embolism, etc) are the leading causes of death, 26814 and respiratory failure often results from these complications. Mortality from respiratory failure is high, especially in patients with a right sided pneumonectomy ${ }^{8114}$ when the largest lung with the largest lymph drainage capacity has been removed.
Moreover, the circulatory effects (pulmonary hypertension and systemic hypotension) of mechanical ventilation after right pneumonectomy, particularly when the remaining lung is diseased, are serious. Left sided pneumonectomy carries less risk, ${ }^{81114}$ and this is reflected by the presence of only two such cases in our series.

Aspiration of blood into the remaining lung was an important cause of postoperative difficulties in our series. It occurred in three patients (cases 11 , $13,15)$, two of whom died. It is therefore a serious complication but one which is potentially avoidable by the routine use of a double lumen, endotracheal tube.

In published reports bronchopleural fistula is a highly feared complication in patients who require mechanical ventilation in the presence of a bronchial suture line, but in our series only one fistula developed during the initial course of mechanical ventilation. Theoretically the use of continuous positive airway pressure decreases this risk because high airway pressures are prevented. Continuous positive airway.pressure also has advantages with respect to the circulation. In the acute phase of respiratory failure, however, its use is often precluded because of the patient's poor ventilatory condition. The use of a double lumen tube permits independent, differentiated, lung ventilation or selective, one sided ventilation and may thus diminish the risk of fistula formation. We currently advocate its use, for a relatively short term, in patients with acute respiratory failure after pneumonectomy if continuous positive airway pressure is not possible or high airway pressures (end inspiratory peak pressure $>3.43 \mathrm{kPa}$ $\left(35 \mathrm{~cm} \mathrm{H}_{2} \mathrm{O}\right)$ ) are inevitable, or both. Meticulous positioning and fixation and frequent control of the position are mandatory. The benefit of high frequency ventilation for this kind of ventilatory problem has still to be evaluated.

Numerous studies have dealt with the estimation of postoperative lung function after resection and the factors that predispose to operative problems. ${ }^{14-6}$ The following indices are considered to be important: $F E V_{1}$ lower than 1.401 , maximum voluntary ventilation (MVV) lower than $60 \%$ of predicted, electrocardiographic abnormalities such as arrhythmias and premature ventricular contractions, and age above 70 years. No single factor seems to predispose to postoperative problems, but these occur especially with a combination of two or more of the above factors. In our series four patients were not recognised to be at high risk; the remaining patients were known to have a moderately increased risk, but respiratory failure was generally related not to these specific risk factors but to unpredictable intraoperative or postoperative events. The low two 
year survival in the initial survivors (three out of eight, $38 \%$ ) was determined by progression of the tumour in all cases. None of the patients had respiratory insufficiency at follow up.

The series is too small to permit comparison with the long term survival of all patients undergoing resection ( $48 \%$ at two years in our hospital), but the survival seems to be lower than might be expected. A satisfactory explanation for this has not so far been found.

\section{CONCLUSIONS AND RECOMMENDATIONS}

Acute respiratory failure after surgery for bronchial carcinoma is an uncommon complication, which often can be neither predicted nor prevented. Patients with acute respiratory failure in the postoperative phase after lobectomy or pneumonectomy must be accepted for mechanical ventilation as it is often successful in patients with a lobectomy and sometimes so in patients with a pneumonectomy. After initial survival long term prognosis is generally determined by the course of the tumour.

The use of continuous positive airway pressure, double lumen tubes, and perhaps high frequency ventilation may, in some selected cases, diminish the risk of bronchopleural fistula formation in patients requiring mechanical ventilation and in this way increase the chance of survival. Double lumen tubes should also be used whenever possible during operation to prevent the intraoperative aspiration of blood or pus. Optimal preoperative treatment of chronic obstructive lung disease-for example, with bronchodilators, corticosteroids, and physiotherapy-is essential to minimise postoperative difficulties. In a few cases a short course of prophylactic postoperative mechanical ventilation may be indicated.

\section{References}

1 Ali MK, Mountain CF, Ewer MS, Johnston D, Haynic TP. Predicting loss of pulmonary function after pulmonary resection for bronchogenic carcinoma. Chest 1980; 77:337-42.

2 Boushy SF, Billig DM, North LB, Helgason AH. Clinical course related to preoperative and postoperative pulmonary function in patients with bronchogenic carcinoma. Chest 1971;59:383-91.

3 Didolkar MS, Moore RH, Takita $H$. Evaluation of risk in pulmonary resection for bronchogenic carcinoma. Am J Surg 1974;127:700-3.

4 Jett JR, Cortese DA, Fontana RS. Lung cancer: current concepts and prospects. $C A$ 1983;33:74-86.

5 Karliner JS, Coomaraswamy R, Williams MH. Relationship between preoperative pulmonary function studies in prognosis of patients undergoing pneumonectomy for carcinoma of the lung. Diseases of the Chest 1968;54:32-8.

6 Lockwood P. The principles of predicting the risk of post-thoracotomy function-related complications in bronchial carcinoma. Respiration 1973;30:329-44.

7 Mittman C. Assessment of the operative risk in thoracic surgery. Am Rev Respir Dis 1961;84:197207.

8 Nagasaki F, Flehinger BJ, Martini N. Complications of surgery in the treatment of carcinoma of the lung. Chest 1982;82:25-9.

9 Tisi GM. Preoperative evaluation of pulmonary function. Validity, indications and benefits. $A m R e v$ Respir Dis 1979;119:293-310.

10 Williams CD, Brenowitz JB. "Prohibitive" lung function and major surgical procedures. Am J Surg 1976;132: 763-6.

11 Smith RE, Williams WG, eds. The Coventry conference on surgery of the lung 1973. London: Butterworth, 1974.

12 Brovold J, Konietzko N, Maassen W. Proceedings, 12th annual meeting, German Society for Thoracic and Cardiovascular Surgery. J Thorac Cardiovasc Surg 1983;85:32 (abstract).

13 Miller JI, Mansour KA, Hatcher CR. Carcinoma of the lung: five-year experience in a university hospital. $\mathrm{Am}$ Surg 1980;46:147-50.

14 Wilkins EW, Scannell JG, Craver JG. Four decades of experience with resections for bronchogenic carcinoma at the Massachusetts General Hospital. J Thorac Cardiovasc Surg 1978; 76:364-8. 